\title{
Comparative Effects of Recast and Metalinguistic Corrective Feedback in Processing Instruction versus Meaningful Output-based Instruction on the Acquisition of Comparative and Superlative Adjectives
}

\author{
Azar Hosseini Fatemi \\ English Department, Ferdowsi University of Mashhad, Iran \\ E-mail: hfatemi@ferdowsi.um.ac.ir \\ Zari Sadat Seyyedrezaie (Corresponding author) \\ Department of English Language Teaching, Aliabad Katoul Branch, Islamic Azad University \\ Aliabad Katoul, Iran \\ Tel: 091-1269-2637 E-mail: Seyyedrezaie_z@yahoo.com \\ Vahideh Sadat Vahedi \\ Islamic Azad University, Qaenat Branch, Qaenat, Iran \\ Tel: 091-5162-5467_E-mail: Vahideh_V2010@yahoo.com
}

Received: September 27, 2013 Accepted: November 13, 2013 Published: November 13, 2013

doi:10.5296/ijele.v2i1.4550 URL: http://dx.doi.org/10.5296/ijele.v2i1.4550

\begin{abstract}
The present study intended to investigate the possible effects of two different types of implicit and explicit corrective feedback (recast and metalinguistic corrective feedback) and two types of grammar instruction, that is Processing Instruction (PI) as an input- based approach and Meaningful Output- Based Instruction (MOBI) with output orientation on learners' acquisition of comparative and superlative adjectives. To this end, 120 participants selected out of 140 Iranian freshman EFL learners, who had taken the pre-university English course, took part in the study. They were assigned into two main instructional groups (PI/ MOBI), each divided into two subgroups, one exposed to metalinguistc corrective feedback
\end{abstract}


and the other to recast one. First, a pretest was administered to determine whether the possible effects gained at the end of the experiment resulted from the treatment itself or was partly due to some prior knowledge of learners. Two weeks after administering the pretest, the treatment started out and the study groups received the instruction of the target structures. At the end of the treatment, the students were given a posttest. The gathered data were analyzed through three independent samples t- tests. The results revealed that learners receiving recast in PI group outperformed their counterparts receiving metalinguistic feedback in the same group. Conversely, learners receiving metalinguistic feedback in MOBI group showed higher grammatical gains than those who received recast. Concerning the general effectiveness of two instructional models, no statistically significant difference was found, though PI group performed better than MOBI one. In sum, this study confirmed the view that providing the opportunity for giving feedback in juxtaposition with the instructional approach triggers noticing the gap between interlanguage and the target forms, which in turn improve the acquisition of L2 grammar.

Keywords: Processing instruction, Meaningful output-based instruction, Metalinguistic feedback, Recast

\section{Introduction}

The understanding of how input and output affect comprehension and production of target forms and structures in one's second language (L2) is a key issue in SLA research and has been the subject of several studies trying to examine the relative effects of input-based as compared to output-based instructional conditions. (Allen, 2000; Collentine, 1998; Erlam, 2003). Today there is a wide consensus that learners' exposure to input plays an essential role in second language acquisition so that it seems rather impossible to conceive learning a new language without considering a role for input in some form or other.

Over the past three decades, a great number of comprehensive reviews have fostered the conclusion that explicit grammar instruction really makes a big difference in language acquisition, as compared with naturalistic exposure to L2 (e.g., Doughty \& Williams, 1998; Ellis, 1994; Norris \& Ortega, 2000). Accordingly, the principal focus of some research (Benati, 2001; Benati, 2005) in L2 instruction has shifted from the question of 'does instruction help?' to the question of 'what types of instruction are more effective for L2 learning in formal contexts?' Within the type-of-instruction research paradigm, many studies (Erlam, 2003; Morgan- Short \& Bowden, 2006) have addressed the relative effectiveness of input-based and output-based instructional options on explicit grammatical knowledge.

Processing Instruction (PI), as an explicit Form-Focused Instruction (FFI), is a pedagogical language instruction developed and revised by VanPatten (2004). VanPatten (2004) believes that the aim of PI is to engage learners in activities which have been manipulated to make language forms more salient so that learners move toward more systematic processing tools in order to acquire those forms more efficiently and successfully.

PI provides 1) explicit, non-paradigmatic grammatical instructions that include input through 
examples and information about processing strategy 2) structured input practice composed of meaningful tasks 3) feedback, so PI provides 2 types of input: a) examples b) structured input. These assumptions led to the development of a new grammar instructional approach known as 'processing instruction' (PI) which mainly aims at helping learners to readjust their inefficient processing strategies. The purpose of PI is to alter how learners process the input and to make them develop better form-meaning mappings which result in a grammatically richer intake. VanPatten (2002b) assumes that an explicit type of instruction with a focus on learners' processing strategies is more effective than approaches which require learners to produce language too prematurely.

In the same way, the role of output is an important issue in SLA. Vanpatten (2008) mentioned that the crucial debate among SLA theorist and practitioner is about output-based instruction as, Swain (1985) and Harley (1993) claimed that comprehensible input alone was not enough for successful SLA. They believed that comprehensible output was also required, so ample opportunities for learners output and provision of useful and consistent feedback was necessary. Although VanPatten (2002a) mentioned that output plays a number of important roles in language development and that, in fact it plays facilitative role in acquisition. In this regard, Meaningful output-based instruction (MOBI) presents learners with paradigmatic grammatical instruction with input through examples, oral and written output-based practices that move from mechanical to meaningful to open-ended communicative tasks.

Following the idea that both input and output-based instruction can be effective for SLA, many studies have attempted to compare the two under variety of research designs (Allen, 2000; Collentine, 1998; Dekeyser \& Sokalski, 1996). But few studies have specifically addressed the interaction between instruction types (PI \& MOBI) and types of corrective feedback. To fill this gap, this study attempted to investigate the effects of different types of corrective feedback (recast and metalinguistic corrective feedback) and instructional models (PI \& MOBI) on learners' acquisition of comparative and superlative adjectives.

To fulfill the purpose of this study, the following research questions were addressed:

1. Do recast and metalinguistic corrective feedback have any statistically differential effect on learners' acquisition of comparative and superlative adjectives in processing instruction model?

2. Do recast and metalinguistic corrective feedback have any statistically differential effect on learners' acquisition of comparative and superlative adjectives in meaningful output-based instruction model?

3. Is there any statistically significant difference in learners' acquisition of comparative and superlative adjectives in PI and MOBI?

\section{Literature Review}

Since recent researches have revealed the need for formal instruction for learners to achieve high levels of accuracy, grammar teaching and its role in second language acquisition has become the focus of most current investigation. As Rutherford (1987, cited in Celce-Murcia, 
1991) points out, in the past for 2500 years, teaching of grammar had often been synonymous with foreign language teaching. However, the necessity of grammar instruction has generated a great debate in L2 teaching for more than 40 years (Ellis, 2001). During the past decades grammar has moved from a position of central importance in language teaching to pariah status, and back to a position of renewed importance (Celce-Murcia, 1991). Several studies (Ellis, 2001; Swain, 1985) have been done on ways to combine some form of grammar instruction with the provision of opportunities for communicative input and output, and a number of studies have researched their effectiveness.

\subsection{Processing Instruction and Meaningful Output-based Instruction}

Processing instruction model as an input-based instructional technique proposed by VanPatten (1996) has been widely referenced in most input processing studies. Three basic characteristics of processing instruction were suggested by Wong and VanPatten (2003). First, learners are given information about a linguistic structure or form. The second characteristic of processing instruction involves learners about a particular input processing strategy that may negatively affect their picking up the form/structure during comprehension. Third, learners are pushed to process the form/structure during activities with structured input, which is manipulated in particular ways so that learners become dependent on form and structure to get meaning, and/or to privilege the form/structure in the input so that learners have a better chance of attending to it. Learners do not produce the structure or form during structured input activities. While Meaningful output- based instruction (Morgan-Short \& Bowden, 2006) consists of structured output activities which are meaningful activities in nature. They all carry a meaningful context and the target forms are produced not with the sole intention of practicing the target item, but rather to communicate opinions, beliefs, or other information related to designated topic.

In the first processing instruction (PI) studies, VanPatten and Cadierno (1993) investigated the impact of processing instruction with meaningful output-based instruction which involved grammar explanations followed by output practice. The results revealed that the PI group was superior to the OI group on the tasks measuring the interpretation of Spanish clitic object pronouns, and equally well on production tasks, though they never produced the grammar feature during the instruction phase. They concluded that instruction is obviously more beneficial if it is directed at how learners perceive and process input rather than focusing on practice via output.

Cadierno (1995) found the same result. In his study, PI group outperformed the OI in interpretation tasks and equally well in production tasks. Benati's (2001) study also supported some evidence that PI had more significant effects on the acquisition of Italian verbal morphology than OI. In his subsequent study, Benati (2004) strengthened the evidence regarding the positive effect of structured input practice in PI with a different structure (gender agreement in Italian adjectives) and a more spontaneous and communicative task. Similarly, in his next experimental study on the acquisition of English past simple tense, Benati (2005) concluded that processing instruction group outperformed both the traditional and the meaningful output-based groups in the interpretation test while the three groups 
improved equally well on their production test.

In contrast, some other studies have failed to produce convincing evidence for the superiority of PI over OI. For example, DeKeyser and Sokalski's (1996) study on Spanish clitic direct object pronoun and conditional structures concluded that input practice worked better for comprehension skills but output practice was better for improving production skills. In addition, the relative effectiveness of production versus comprehension practice is related to the complexity of the target structure and on the delay between practice and testing. Allen (2000) did not find any advantages for PI over OI group in how they interpreted the French causative, while OI proved to be more effective in enabling learners to produce the form. In a study by Erlam (2003), he compared the effects of the two approaches on the students' ability to comprehend and produce direct object pronouns in French; and found greater gains for OI group. Celik-Yazici's (2007) study indicated no significant difference between PI and OI in comprehension and production tasks as far as the development of English wh-questions by Turkish EFL learners was concerned.

\subsection{Corrective Feedback}

Corrective feedback, defined by Lightbown and Spada (1999) as "any indication to the learners that their use of the target language is incorrect" (p. 171) can be considered as a kind of modified input, and may lead to modified output on the part of the learner. According to Swain (1995, cited in Abadikhah \& Ashoori, 2012), as learners struggle to test their hypotheses, the external feedback (implicit or explicit) provided by their teachers can help them notice the problems in their interlanguage. When there is no external feedback, learners do not have anything to test their hypotheses against. Two types used in the present study will be defined.

Recast is one type of implicit reformulation move that has received increasing attention in both L1 and L2 context is the recast - a well formed reformulation of learner's non target utterance with the original meaning intact. Recast defined by Lyster and Ranta (1997) as "the teacher's reformulation of all or part of a student's utterance, minus the error" (p. 46). Long (2007) asserted that a recast is a discourse move that is by definition implicit, whereas Lyster (1998, cited in Rastegar Haghighi Shirazi \& Sadighi, 2012) referred to implicit function of recast in providing a reformulation. Doughty and Varela (1998) conducted a study on the effectiveness of the corrective recasts and reported that learners who received corrective recasts outperformed the control group in both oral and written measure.

Metalinguistic feedback was defined by Lyster and Ranta (1997, cited in Gholami \& Talebi, 2012) as comments, information, or questions related to the well-formedness of the learner's utterance. Metalinguistic feedback can lead learners to self-repair, whereas recasts can lead only to repetition of correct forms by students. Lyster (2007) argued that self-repair following a metalinguistic feedback requires a deeper level of processing than repetition of a teacher's recast. Self-repair is thus more likely to destabilize interlanguage forms as learners are pushed to reanalyze interlanguage representations and to attend to the retrieval of alternative forms. In contrast to self-repair following a metalinguistic feedback, repetition of recast does not engage learners in a similarly deep level of processing nor necessitate any reanalysis. 
In this vein, Sauro (2009) found no difference between the effectiveness of recast and metalinguistic feedback on the development of L2 grammar among intermediate and advanced learners of English. Results showed no significant advantage for either feedback type on immediate or sustained gains in target form knowledge, although the metalinguistic group showed significant immediate gains relative to the control condition.

\section{Method}

\subsection{Participants}

The participants of the present study were 120 Iranian freshman male and female students of management chosen out of 140 students based on their Preliminary English Test (PET) language proficiency test scores. The participants had enrolled in 'pre-university English' course as a required part of the university curriculum at Islamic Azad University, Aliabad Katool branch. The participants aged from 18 to 25 years old. They were then randomly assigned into two instructional groups (processing instruction/ meaningful output-based instruction), each group divided into two subgroups, one subgroup receiving recast as a kind of corrective feedback and the other one receiving metalinguistic corrective feedback. They were the students who had little or no previous knowledge of the target structure, which was measured by administrating a grammar pretest. They had no exposure to the target form outside the class during the treatment period.

\subsection{Target Structure}

English comparative and superlative adjectives were chosen as the target structures for the present study.

Comparative adjectives:

The suffix _er and preposition than are included for one syllable adjectives and more......than combination for two and multi-syllable adjectives.

Taj Mahal is older than Eiffle Tower. Health is more important than money.

Superlative adjectives:

When a number of things, three or more, are compared, we use superlative adjectives. It is also used when one is compared with a few. The suffix -est is added to one-syllable adjectives and most to two and multi-syllable adjectives.

Running is the cheapest sport. The best west motel is the most expensive motel in town.

These target structures were chosen after considering VanPatten's primacy of content words principle (VanPatten, 1996). According to this principle, learners tend to pay more attention to content words at the expense of ignoring function words in order to obtain maximum information from input. More specifically, comparative and superlative adjectives in the above sentences have low communicative value and are low in saliency because such sentences are easily understandable even by ignoring the distinction between -er and -est; more and most 
function words. Thus, the above target structures can be considered as appropriate target structures to examine the effects of input-based and output-based instruction.

\subsection{Instrumentation}

\subsubsection{Developing and Training Treatment Packs}

Two separate packs of PI and OI were developed based on the VanPatten's (2002 a) guidelines. The PI pack was comprised of (1) a brief script of metalinguistic information about the target form, (2) some explicit explanation about the typical processing problems that learners usually have in interpreting or producing comparative and superlative adjectives, and (3) structured input activities that were made up of 15 pictorial and non-pictorial sentences. Both types of activities were then designed in a way to push learners to process (not to produce) the information presented in the input containing the comparative and superlative adjectives. The MOBI pack was comprised of (1) the same brief script of metalinguistic information about the comparative and superlative adjectives included in the PI pack, and (2) production activities (20 pictorial and non-pictorial sentences) requiring the participants to use the comparative and superlative adjective forms and complete the written tasks.

\subsubsection{Assessment Tasks}

To assess the possible effects of the instruction models and different types of corrective feedback, a pretest and posttest were used. The pretest consisted of two sections. The first section included the interpretation test which consisted of 15 pictorial and non-pictorial items, 10 of which were critical. The students were required to answer multiple choice questions using their gained knowledge of comparative adjectives during the course of the treatment. The second section composed of 14 production items, 10 of which were critical. Participants were required to complete a sentence that corresponded to the related picture or given sentences using the correct form of the adjective that was provided. The distracters required the use of simple adjectives. For validating the content of the test, it was reviewed by a panel of two Iranian university faculty members. As the result of the panel review, some items or pictures were eliminated or modified. Following VanPatten and Cadierno (1993), another similar version of the pretest was designed. The reason behind this was that to use a splitblock design and to remove the possible practice effect. The two versions were exactly the same in terms of format, instructions, the number of target and distracter items and timing. The order of items had just changed and some synonyms had been used.

\subsection{Procedure}

At the beginning of the current study, the Preliminary English Test (PET) was administered in order to ensure the homogeneity of the participants. Out of the total 140 students who participated in this study, 120 were included in the study. They were assigned into two main instructional groups (processing instruction/ meaning output- based instruction), each divided into two subgroups, one exposed to recast and the other to metalinguistic feedback. The data were gathered through different stages. First, a pretest was administered which was the equivalent version of the posttest. The reason behind its administration was to determine 
whether the possible effects gained at the end of the experiment resulted from the treatment itself or was partly due to some prior knowledge of learners. Two weeks after administering the pretest, the treatment started out and the study groups received the instruction of the target structure. Two different instruction packages (processing instruction and meaningful outputbased instruction) were used in this study. The participants taught through processing instruction package were first given explicit instruction of the target structure and then they were engaged in activities designed based on VanPatten's (2002 a) processing instruction guidelines. On the other hand, participants taught through meaningful output-based instruction package were first given the same brief script of metalinguistic information about the target structures included in the PI package, then they are involved in production activities requiring participants to use target structures to complete the written tasks. All groups were provided with feedback when learners' interlanguage differed from the target form as far as the comparative adjectives were concerned. The experiment lasted for two weeks and all groups were taught by the same teacher to remove any possible interactional effect related to teachers' different individual or methodological characteristics. After the end of the experiment, the participants were given the posttest to assess and compare the effectiveness of instructional models and different types of corrective feedback on learners' uptake of comparative adjectives. The result of posttest, when gathered and analyzed statistically, provided the answer to the proposed research questions.

\subsection{Rating Scale}

Scoring procedure was based on the following criteria. The multiple choice interpretation test was scored by awarding one point per each correct response and no point per incorrect one. In production test items, the raw scores were calculated as follows:

- Fully correct comparative adjectives $=1$ point

- $\quad$ Partially correct $=0.5$ point

- $\quad$ Incorrect $=0$ point

In order to achieve inter-rater reliability, two raters who were experienced teachers scored the items based on the same criteria.

\section{Result}

The present study was an effort to find evidence for the effects of two types of implicit and explicit corrective feedback, opertionalized as recast (implicit) and metalinguistic feedback (explicit) in this study, and instruction models (PI vs. MOBI) on learners' acquisition of comparative and superlative adjectives. In this vein, after exposing learners to experimental treatments in each group, the data were analyzed using descriptive and inferential statistics.

The first assumption to be tested was whether experimental groups in this study were homogeneous prior to the experiment based on their performance in pretest. This was checked through the Test of Homogeneity and the results are presented in Table 1. 
Table 1. Test of Homogeneity of Variances for pretest scores

\begin{tabular}{|l|l|l|l|}
\hline $\begin{array}{l}\text { Levene } \\
\text { Statistic }\end{array}$ & df1 & df2 & Sig. \\
\hline 1.091 & 1 & 118 & .298 \\
\hline
\end{tabular}

As is indicated in the above table, there was no statistically significant difference between four groups at the beginning of the experiment.

Second, in order to check the normality assumption of the distributed scores in each group (PI/ MOBI) and the legitimacy of using parametric tests, one- sample Kolmogorov- Smirnov test was run (Table 2).

Table 2. One-Sample Kolmogorov-Smirnov Test (for PI \& MOBI groups)

\begin{tabular}{|l|l|l|}
\hline & Test score (PI) & $\begin{array}{l}\text { Test score } \\
\text { (MOBI) }\end{array}$ \\
\hline $\mathrm{N}$ & 60 & 60 \\
Normal & 14.01 & 14.53 \\
Mean & 2.65 & 2.89 \\
Parameters & 1.36 & 1.36 \\
Std. Deviation & .04 & .04 \\
Kolmogorov-Smirnov Z & & \\
Asymp. Sig. (2-tailed) & & \\
\hline
\end{tabular}

According to the above results, it is clear that the samples were drawn from a normal distribution since the P-value was greater than .05.

In order to answer the first research question stating that whether recast and metalinguistic corrective feedback have any statistically differential effect on learners' acquisition of comparative and superlative adjectives in processing instruction group, the participants' scores on the posttest were gathered and tabulated. The descriptive statistics for the two groups receiving two different types of corrective feedback (recast/ metalinguistic feedback) when exposed to processing instruction are presented in Table 3.

Table 3. Descriptive Statistics for PI group

\begin{tabular}{|l|l|l|l|l|l|}
\hline & feedback type & N & Mean & Std. Deviation & $\begin{array}{l}\text { Std. Error } \\
\text { Mean }\end{array}$ \\
\hline test score & Recast & 30 & 18.06 & 1.46 & .26 \\
\cline { 2 - 7 } & $\begin{array}{l}\text { metalinguistic } \\
\text { feedback }\end{array}$ & 30 & 10.66 & 1.24 & .22 \\
\hline
\end{tabular}


On inspection of the mean scores, one can conclude that learners receiving recast corrective feedback performed better in posttest than those receiving metalinguistic feedback, although the mean scores of the two groups were very close to each other in pretest, indicating that they started out the experiment with similar knowledge of the target structure. This result suggests that despite the same instructional model, the two groups showed dissimilar performances after receiving different types of corrective feedback. To put it in other words, two types of corrective feedback seemed to have some effects on enhancing learners' uptake of comparative adjectives, but not the same effect.

Since descriptive statistics alone are not strong enough, an independent samples t- test was performed to detect any statistically significant difference between the performance of the two groups (Table 4).

Table 4. Independent Samples T-Test for Equality of Means (PI group)

\begin{tabular}{|c|c|c|c|c|c|c|c|c|}
\hline & \multicolumn{7}{|c|}{$\begin{array}{l}\text { Levene's Test for } \\
\text { Equality of Variances } t \text {-test for Equality of Means }\end{array}$} \\
\hline & & \multirow[b]{2}{*}{$F$} & \multirow[b]{2}{*}{ Sig. } & \multirow[b]{2}{*}{$\mathrm{T}$} & \multirow[b]{2}{*}{ df } & \multirow{2}{*}{$\begin{array}{l}\text { Sig. } \\
\text { (2-tailed) }\end{array}$} & \multicolumn{2}{|c|}{$\begin{array}{l}95 \% \text { Confidence } \\
\text { Interval of the } \\
\text { Difference }\end{array}$} \\
\hline & & & & & & & Lower & Upper \\
\hline $\begin{array}{l}\text { test } \\
\text { score }\end{array}$ & $\begin{array}{l}\text { Equal variances } \\
\text { assumed }\end{array}$ & 37 & .54 & 21.14 & 58 & .00 & 6.69 & 8.10 \\
\hline
\end{tabular}

The results reported in Table 5 showed that $\mathrm{P}$ - value was less than the level of significance set in this analysis $(\mathrm{P}=.000<.05)$, suggesting that exposing learners to recasts had improved the learners' uptake of comparative adjectives.

To have a more informative picture of the above result, figure 1 depicts the learners' performance in pretest and posttest before and after administering the treatment in PI group.

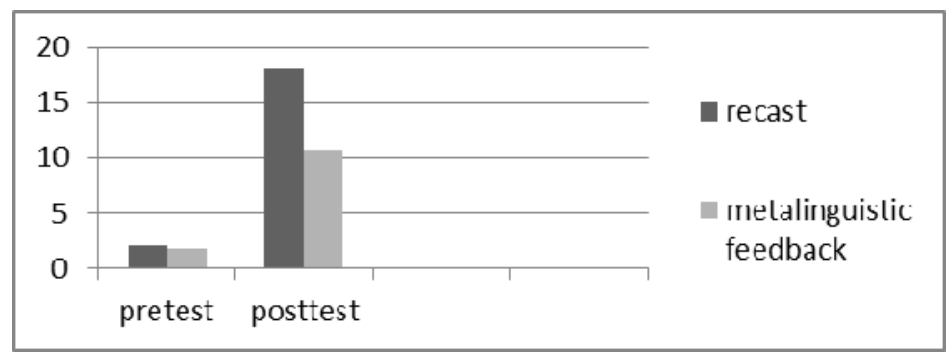

Figure 1. Learners' Pretest and Posttest Mean Scores in PI Group

A short look at the above figure makes it clear that the two experimental groups receiving two 
different types of feedback while taught on the same instruction model (PI) did gain higher grammatical knowledge concerning the use of comparative adjectives in comparison to their pretest. Despite this similarity of instructional model there is a difference in the effectiveness of two types of feedback that catch the attention in Figure 1. The group receiving recasts gained more on the posttest than their counterparts who had received metalinguistic feedback.

The second research question intended to explore whether recast and metalinguistic corrective feedback had any statistically differential effect on learners' acquisition of comparative and superlative adjectives in meaningful output-based instruction group. The descriptive statistics for the two groups taught through the same instruction model (outputbased instruction) but receiving two different kinds of corrective feedback (recast vs. metalinguistic feedback) are presented in Table 5 below.

Table 5. Descriptive statistics for MOBI Group

\begin{tabular}{|l|l|l|l|l|l|}
\hline & feedback type & $\mathrm{N}$ & Mean & $\begin{array}{l}\text { Std. } \\
\text { Deviation }\end{array}$ & $\begin{array}{l}\text { Std. Error } \\
\text { Mean }\end{array}$ \\
\hline \multirow{2}{*}{ test score } & recast & 30 & 12.40 & 1.97 & .36 \\
\cline { 2 - 6 } & $\begin{array}{l}\text { metalinguistic } \\
\text { feedback }\end{array}$ & 30 & 16.66 & 1.93 & .35 \\
\hline
\end{tabular}

As is clear, the mean scores of the two groups are different. To see whether this difference is statistically significant, an independent samples t- test was run (Table 6).

Table 6. Independent Samples T-Test for Equality of Means (MOBI group)

\begin{tabular}{|c|c|c|c|c|c|c|c|c|}
\hline & \multicolumn{2}{|c|}{$\begin{array}{l}\text { Levene's Test fo } \\
\text { Equality of Variances }\end{array}$} & \multicolumn{5}{|c|}{ t-test for Equality of Means } \\
\hline & & \multirow[b]{2}{*}{$\mathrm{F}$} & \multirow[b]{2}{*}{ Sig. } & \multirow[b]{2}{*}{$\mathrm{t}$} & \multirow[b]{2}{*}{ df } & \multirow{2}{*}{$\begin{array}{l}\text { Sig. } \\
\text { (2-tailed) }\end{array}$} & \multicolumn{2}{|c|}{$\begin{array}{l}95 \% \text { Confidence } \\
\text { Interval of the } \\
\text { Difference }\end{array}$} \\
\hline & & & & & & & Lower & Upper \\
\hline test score & $\begin{array}{l}\text { Equal } \\
\text { variances } \\
\text { assumed }\end{array}$ & .000 & .98 & -8.44 & 58 & .00 & -5.27 & -3.25 \\
\hline
\end{tabular}

The results presented in the above table indicated that there was a statistically significant difference between the performances of learners who received metalinguistic feedback in comparison with those who were provided with recasts. That is, metalinguistic feedback 
proved to be more effective than recasts in meaningful output- based instruction group.

The above findings have been depicted in Figure 2.

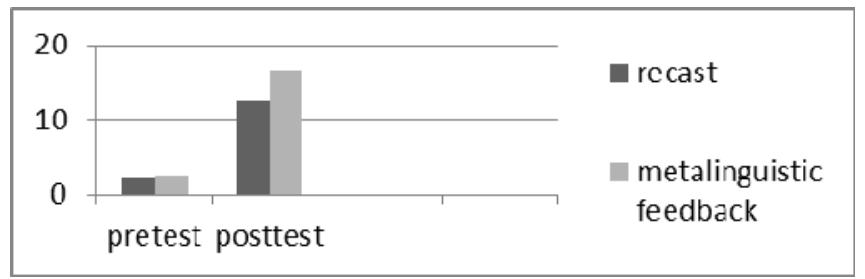

Figure 2. Learners' Pretest and Posttest Mean Scores in MOBI Group

The third research question intended to explore whether there is any statistically significant difference in learners' acquisition of comparative and superlative adjectives in PI and MOBI groups. The result of descriptive statistics concerning the performance of learners in two groups (PI/ MOBI) has been presented in Table 8.

Table 7. Descriptive Statistics for PI and MOBI groups

\begin{tabular}{|l|l|l|l|l|l|}
\hline & \multirow{2}{*}{ instru } & $\mathrm{N}$ & Mean & Std. Deviation & $\begin{array}{l}\text { Std. Error } \\
\text { Mean }\end{array}$ \\
\hline \multirow{2}{*}{ test score } & PI & 60 & 14.05 & 2.66 & .34 \\
\cline { 2 - 7 } & MOBI & 60 & 14.53 & 2.89 & .37 \\
\hline
\end{tabular}

In order to see whether the difference between the mean score of the two groups reported above is statistically significant, a two- way ANOVA was performed (Table 8).

Table 8. Tests of Between-Subjects Effects

Dependent Variable: test score

\begin{tabular}{|l|l|l|l|l|l|}
\hline Source & $\begin{array}{l}\text { Type III Sum } \\
\text { of Squares }\end{array}$ & df & Mean Square & F & Sig. \\
\hline Corrected Model & $359.42^{\mathrm{a}}$ & 3 & 119.80 & 24.75 & .000 \\
\hline Intercept & 24510.20 & 1 & 24510.20 & 5064.75 & .000 \\
\hline Instru & 7.00 & 1 & 7.00 & 1.44 & .23 \\
\hline Feedback & 29.00 & 1 & 29.00 & 5.99 & .016 \\
& & & & & \\
\hline
\end{tabular}




\begin{tabular}{|l|l|l|l|l|l|}
\hline instru * feedback & 323.40 & 1 & 323.40 & 66.82 & .000 \\
\hline Error & 561.36 & 116 & 4.83 & & \\
\hline Total & 25431.00 & 120 & & & \\
\hline Corrected Total & 920.79 & 119 & & & \\
\hline
\end{tabular}

Note the sig. (i.e. p-value) for each F ratio. There is a significant main effect for "feedback", but the main effect for "instruction" is not significant. In addition there is a significant interaction between "feedback" and "instruction" meaning that the proficiency factor has the same effects upon male and female groups.

\section{Discussion}

The current study was designed to explore the possible differential effects of two different kinds of implicit and explicit corrective feedback (recast/ metalinguistic feedback) on learners' intake of comparative and superlative adjectives while exposed to one of the instructional models ( processing instruction / meaningful output- based instruction).

By receiving feedback, learners had the rich opportunity of comparing their own responses with the target forms cognitively. "The feedback provided a condition in which learners could test their generated hypotheses and were able to confirm or disconfirm their grammar as manifested in their output" (Doughty, 2001 cited in Abadikhah \& Ashoori, 2012, p. 122). Concerning the general effect of corrective feedback, the result of this study confirmed the superiority of learners' posttest scores compared to their pretest ones in all study groups, indicating that exposing learners to the target structure in juxtaposition with consciousnessraising activities such as error correction can improve the learners' uptake of grammatical structures. This finding is supported by Swain's (1995) claim that corrective feedback helps learners to replace their incorrect hypotheses about the target language with the correct ones. In other words, learners' attention to the target structures at comparison stage helps them correct their own errors. This is in line with Schmidt's (1990) noticing hypothesis which emphasized the role of feedback in drawing students' attention to form and recognizing the gap between their linguistic knowledge and the target forms.

To be more specific, in the present study three research questions were raised at the onset. Concerning the first research question, it was found that learners receiving recast outperformed in posttest in comparison with their counterparts in processing instruction group who had received metalinguistic feedback. One justification for the above finding can be that according to Yang and Lyster (2010), recast is considered as "input- providing" corrective feedback, which is in accordance with processing instruction guidelines, where the great emphasis is put on input rather than output. Furthermore, as Schmidt (2001) emphasizes, recast provides learners with comprehensible input and a focus on form. 
This finding is consistent with Doughty and Varela's (1998) study which emphasized the positive effect of recasts and reported that the group received corrective recasts outperformed the control group. It also supports the idea of some researchers' (e.g. Long, 2006; Doughty, 2001) view that recast is an effective corrective feedback technique. However, it is in sharp contrast with the claim of those researchers who propose recast as an ineffective technique for interlanguage development so far as some learners pass recasts unnoticed and hence, lose the corrective function of recasts. (Panova \& Lyster, 2002 cited in Rezaei, Mozaffari, \& Hatef, 2011, p. 23). Moreover, Loewen and Philp's (2006) study provide counterarguments for the above finding, since they believe that recasts cannot be very effective because learners are just exposed to the correct form of target structures as modified input, while neglecting the important role of output; that is pushing the learners to correct their interlanguage and elicit their self-repair.

With regard to the second research question, the analysis of data revealed that metalinguistic feedback yielded more effective results than recasts, since participants receiving metalinguistic corrective feedback outperformed those receiving recasts in meaningful output- based instruction group.

One explanation can be that metalinguistic feedback is "output- pushing" (Yang \& Lyster, 2010), the feature which is the cornerstone of meaningful output- based instruction.

Another justification behind the less effectiveness of recast may be the fact that learners in meaningful output- based instruction group are accustomed to self- production and hence ignoring the teacher's reformulation as a corrective feedback, assuming it was a mere positive evidence for their output.

Swain's (1995) output hypothesis also provides a support for the effectiveness of metalinguistic feedback in meaningful output- based instruction group. While producing output, learners may face some difficulties in conveying their meaning. By exposing them to metalinguistic feedback, they are pushed to analyze and modify their output (self-repair) with focused attention to the teacher's mentioned gap.

Another supportive evidence is that a great body of research (e.g. Panova \& Lyster, 2002; Rezaei, Mozaffari, \& Hatef, 2011) has been done to investigate the effectiveness of implicit corrective feedback such as recasts, as the most frequently used corrective feedback, and the results of these surveys had revealed the lowest rate of uptake resulting from such corrective feedback techniques; whereas explicit corrective feedback such as metalinguistic one has proven to lead to the highest rate of uptake. This may be rooted in Schmidt's (2001) noticing hypothesis which emphasizes the importance of attracting the learners' attention to formal aspects of language for achieving linguistic development. In this vein, metalinguistic feedback provides a good stimulus for learners to overtly identify the gap or mismatch between their interlanguage and the target forms.

This finding is in accordance with those studies (e.g. Allwright, 1975; Hendrickson, 1978, cited in Rezaei, Mozaffari, \& Hatef, 2011) which emphasize that "pushing learners in their output rather than providing them with correct forms could benefit their interlanguage 
development" (p. 25). In other words, the use of corrective feedback should be delayed to provoke learners for self-repair (Allwright \& Bailey, 1992).

However, the effectiveness of metalinguistic feedback is against Ellis's (1994) view that recasts provide good conditions for cognitive comparison because they increase learners' noticing on form.

The third finding of this study revealed that learners in processing instruction group totally gained grammatically richer gains compared to their counterparts in meaningful outputbased instruction group, although this difference was not statistically significant.

This finding lends support to VanPatten's (2002 a) view that processing instruction helps learners modify their interlanguage and improve their processing strategies. It is also in line with VanPatten and Wong's (2004) study which confirmed the superiority of processing instruction over meaningful output- based instruction on the acquisition of French faire causatives. Furthermore, it is in line with the findings of VanPatten and Cadierno's (1993) study, in which the effect of processing instruction and meaningful output- based instruction on the acquisition of direct object pronoun was investigated. The result from the statistical analysis of data revealed that processing instruction group was superior to meaningful outputbased instruction group.

The proponents of output hypothesis posit a contradictory view which under questions the effectiveness of processing instruction. Working from an output- based perspective; they do not reject the outstanding role of input in the development of linguistic system. They do, however, deny the view of those researchers (e.g. Krashen, 1981; VanPatten, 1996) who believe that input alone is enough for language learning, and they emphasize that output should be also integrated in the process of L2 learning in addition to- not in opposition to- the crucial role of input ( Izumi, 2002, cited in Morgan- Short \& Bowden, 2006).

\section{Conclusion}

Concerning the first research question which dealt with investigating whether recast and metalinguistic corrective feedback have any statistically differential effect on learners' written accuracy performance of comparative adjectives in processing instruction group, the obtained findings through independent samples t-test revealed that learners receiving recast as a kind of corrective feedback performed better in posttest than those receiving metalinguistic feedback. The result supports the belief of Yang and Lyster (2010). These researchers considered recast as 'input providing' corrective feedback, which is in line with processing instruction guidelines.

Concerning the second research question raised to see whether recast and metalinguistic corrective feedback have any statistically differential effect on learners' written accuracy performance of comparative adjectives in meaningful output-based instruction group, an independent samples t-test was conducted. The result indicated that learners receiving metalinguistic corrective feedback worked better than those receiving recast in meaningful output-based instruction group. This result also supports the explanation of Yang and Lyster (2010) about metalingustic feedback which illustrated that it is output-pushing which is in 
accordance with meaningful output-based instruction guideline.

Concerning the third research question, stating that whether there is any statistically significant difference in learners' uptake of comparative adjectives in PI and MOBI, an independent sample t-test indicated that although both types of instructions (PI \& MOBI) showed a positive improvement in learners' written accuracy performance, the effects of PI was more evident than MOBI.

The findings of this study brought about some pedagogical implications for EFL curriculum developers, teachers, learners, and those preparing grammar textbooks. Given the benefits that PI brought about in the present study, the findings showed that focusing learners' attention on the formal characteristics of the target structures facilitates the rate of EFL learning. Also the findings pointed out that explicit grammar instruction through processing instruction model was beneficial in making the learners in the instructional groups notice the target structures' recognition and use in L2.

Concerning the results of current study along with those of PI studies, output studies, and studies examining the relative effects of input and output, the findings suggest that input as well as output can promote linguistic development and it might contribute to have a direct path to acquisition via the establishment and strengthening of form-meaning orientation.

The present study contained some limitations that one should bear in mind in order to avoid undue generalizations. First, this study included only Iranian freshman male and female students of management. A more comprehensive study including other EFL learners with different proficiency levels will contribute to the understanding of the effects of two different kinds of implicit and explicit corrective feedback (recast/ metalinguistic feedback) on learners' acquisition of comparative and superlative adjectives while exposed to one of the instructional models ( processing instruction / meaningful output- based instruction). The second limitation was that because of administration constraints, including time restrictions, only comparative and superlative adjectives were examined; other research can examine different kinds of grammatical structures. The third limitation of the study was that participants were not provided with opportunities for more natural and communicative use of target forms.

\section{References}

Abadikhah, Sh., \& Ashoori, A. (2012). The effect of written corrective feedback on EFL learners' performances after collaborative output. Journal of language Teaching and Research, 3(1), 118-125. http://dx.doi.org/10.4304/JLTR.3.1.118-125

Allen, L. Q. (2000). Form-meaning connections and the French causative: An experiment in processing instruction. Studies in Second Language Acquisition, 22, 69-84.

Allwright, D., \& Baily, K. M. (1992). Focus on the classroom: An introduction to classroom research for language teachers. Cambridge: Cambridge University Press.

Benati, A. (2001). A Comparative study of the effects of processing instruction and outputbased instruction on the acquisition of the Italian future tense. Language Teaching Research, 
$5(2), 95-127$.

Benati, A. (2004). The effects of processing instruction and its components on the acquisition of gender agreement in Italian. Language Awareness, 13(2), 67-80.

Benati, A. (2005). The effects of processing instruction, traditional instruction and meaning-output instruction on the acquisition of the English past simple tense. Language Teaching Research, 9(1), 67-93.

Cadierno, T. (1995). Formal instruction from a processing prospective: An investigation into the Spanish past tense. Modern Language Journal, 79(2), 179-193.

Celce-Murcia, M. (1991). Grammar pedagogy in second and foreign language teaching. TESOL Quarterly, 25(3), 459-480.

Celik-Yazici, I. (2007). A study of the effects of processing instruction on the development of English WH-questions by Turkish EFL learners. Interlinguistica, 17, 250-260.

Collentine, J. (1998). Processing instruction and the subjunctive. Hispania, 81, 576-587.

DeKeyser, R., \& Sokalski, K. (1996). The differential role of comprehension and production practice. Language Learning, 46, 613- 642.

Doughty, C., \& Williams, J. (1998). Focus on form in classroom second language acquisition. Cambridge University Press.

Ellis, R. (1994). The study of second language acquisition. Oxford: OUP.

Ellis, R. (2001). Form-focused instruction and second language learning. Malden, MA: Blackwell.

Erlam, R. (2003). Evaluating the relative effectiveness of structured-input and output-based instruction in foreign language learning: Results from an experimental study. Studies in Second Language Acquisition, 25, 559-582.

DeKeyser, R., \& Sokalski, K. (1996). The differential role of comprehension and production practice, Language Learning, 46, 613- 642.

Doughty, C. (2001). Instructed SLA: Constraints, compensation, and enhancement. In C. Doughty \& M. Long, (Eds.), Handbook of second language acquisition (pp. 256-310). New York: Blackwell.

Doughty, C., \& Varela, E. (1998). Communicative focus on form. In C. Doughty \& J. Williams (Eds.), Focus on Form in classroom second language acquisition (pp. 114-138). New York: Cambridge University Press.

Gholami, J., \& Talebi, Z. (2012). The effects of implicit and explicit feedback on EFL learners' grammatical accuracy: The case of regular past tense in English. International Journal of Physical and Social Sciences, 2(6), 39-62. 
Harely, B. (1993). Instructional strategies SLA in early French immersion. Studies in Second Language Acquisition, 15, 245-259.

Krashen, S. (1981). Second Language Acquisition and Second Language Learning. Oxford: Pergamon Press.

Lightbown, P. M., \& Spada, N. (1999). How languages are learned. Oxford, UK: Oxford University Press.

Loewen, S., \& Philp, J. (2006). Recasts in the adult English L2 classroom: Characteristics, explicitness, an effectiveness. Modern Language Journal, 90, 536-555.

Long, M. (2006). Problems in SLA. Mahwah, NJ: Lawrence Erlbaum Associates.

Lyster, R. (2007). Learning and teaching languages through content: A counterbalanced approach. Amsterdam: Benjamins.

Lyster, R., \& Ranta, L. (1997). Corrective feedback and learner uptake: Negotiation form in communicative classrooms. Studies in Second Language Acquisition, 19, 37-66.

Morgan- Short, K., \& Bowden, H. W. (2006). Processing instruction and meaningful outputbased instruction. Studies in Second Language Acquisition, 28, 31-65. http://dx.doi.org/10.1017/S0272263106060025

Norris, J. M., \& L. Ortega (2000). Effectiveness of L2 instruction: A research synthesis and quantitative meta-analysis. Language Learning, 50(3), 417-528.

Panova , I. , \& Lyster, R. ( 2002). Patterns of corrective feedback and uptake in an adult ESL classroom . TESOL Quarterly, 36, 573-595.

Rastegar Haghighi Shirazi, Z., \& Sadighi, F. (2012). Implicit versus explicit feedback in classroom: An experimental study. Journal of Language Teaching and Research, 3(3), 439-445. http://dx.doi.org/10.4304/JLTR.3.3.439-445

Rezaei, S., \& Mozaffari, F., \& Hatef, A. (2011). Corrective Feedback in SLA: classroom practice and future directions. International journal of English linguistics, 1(1), 21- 29.

Sauro, Sh. (2009). Computer-mediated corrective feedback and the development of L2 grammar. Language Learning \& Technology, 12(1), 96-120.

Schmidt, R. (1990). The role of consciousness in second language learning. Applied Linguistics, 11, 17-46.

Schmidt, R. (2001). Attention. In P. Robinson (Ed.), Cognition and second language instruction (pp. 3-32). Cambridge: Cambridge University Press.

Swain, M. (1985). Communicative competence: Some roles of comprehensible input and comprehensible output in its development. In S. Gass, \& C. Madden (Eds.), Input in Second Language Acquisition (pp. 235-253). Rowley. MA: Newbury House. 
Swain, M. (1995). Three functions of output in second language learning. In G. Cook B. Seidlhofer (Eds.), Principle and practice in applied linguistics; Studies in honor of William E. Rutherford (pp. 125-144). Oxford: Oxford University Press.

VanPatten, B. (1996). Input processing and grammar instruction in second language acquisition. Norwood, NJ: Ablex.

VanPatten, B. (2002a). Processing instruction: An update. Language Learning, 52, 755-803.

VanPatten, B. (2002b). Processing the content of input processing and processing instruction research: A response to DeKeyser, Salaberry, Robinson and Harrington. Language Learning, $52,825-831$.

VanPatten, B. (2004). Processing instruction: Theory, research and commentary. NJ: Lawrence Erlbaum Associates.

VanPatten, B. (2008). Processing instruction: Theory, research, and commentary. Second Language Acquisition Research, Lawrence Erlbaum Association, Inc., Publishers.

VanPatten, B., \& Cadierno, T. (1993). Input processing and second language acquisition: A role for instruction. Modern Language Journal, 77, 45-57.

VanPatten, B., \& Wong, W. (2004). Processing instruction and the French causative : Another replication. In B. VanPatten (Ed.), Processing instruction: Theory, research, and commentary (pp. 97-118). Mahwah, NJ: Erlbaum.

Wong, W., \& VanPatten, B. (2003). The evidence is IN: Drills are out. Foreign Language Annals, 36(3), 403-423.

Yang, Y., \& Lyster, R. ( 2010 ). Effects of form-focused practice and feedback on Chinese EFL learners' acquisition of regular and irregular past tense forms. Studies in Second Language Acquisition, 32, 235-263.

\section{Copyright Disclaimer}

Copyright reserved by the author(s).

This article is an open-access article distributed under the terms and conditions of the Creative Commons Attribution license (http://creativecommons.org/licenses/by/3.0/). 